UDC $669.15 ' 3.017: 539.388 .2$

621.983 .016 .3

\title{
$\mathrm{Cu}-\mathrm{Fe}$ 合金の機械的性質について
}

福井彰一*，渡辺敏幸**，礒川憲二**

\section{On the Mechanical Properties of Cu-Fe Alloys}

\author{
Shôichi Fukui, Toshiyuki Watanabe \\ and Kenji Isokawa
}

\begin{abstract}
Synopsis
Mechanical properties, metallurgical structures and fiber textures of $\mathrm{Cu}-\mathrm{Fe}$ alloys were investigated and the following results were obtained.

(1) The quenched $\mathrm{Cu}-\mathrm{Fe}$ alloys are harder than the slowly cooled $\mathrm{Cu}-\mathrm{Fe}$ alloys after holding at the temperature range over the eutectic point, and the faster the cooling rate is, the larger the difference of hardness becomes.

(2) Cu-Fe alloys subjected to severe cold drawing come to have fine fibrous structures. On the said occasion the Fe-rich phases have strong $\langle 110\rangle \alpha$ fiber texture, but the Cu-rich phases only have weak $\langle 111\rangle \varepsilon$ fiber texture.

(3) When the specimens are annealed at $800^{\circ} \mathrm{C}$ below the eutectic point, the Cu-rich phases recrystallize and come to have strong $\langle 111\rangle \varepsilon$ fiber texture even before the recovery of the elongation. On the other hand the Fe-rich phases grow in size with the lapse of time. When they reach to a certain size, the elongation also reaches to a certain amount. The growth of the Fe-rich phases are in good accordance with the recovery of the elongation.
\end{abstract}

\section{1. 緒言}

冷間加工した $\mathrm{Cu}-\mathrm{Fe}$ 合金は常温ではそれぞれ少量 の $\mathrm{Cu}$ まは $\mathrm{Fe}$ を固溶しだ〉微細なファイバザの Fe-rich 相（結晶構造は b·c·c で以下 $\alpha$ 相と称す る）と Cu-rich 相（結晶構造は $\mathrm{f} \cdot \mathrm{c} \cdot \mathrm{c}$ で以下 $\boldsymbol{\varepsilon}$ 相 と称する）の混合組織から成っており，しかも $\alpha+\varepsilon$ ‡ $\gamma(\gamma$ は結晶構造は $\mathrm{f} \cdot \mathrm{c} \cdot \mathrm{c})$ の共析変態があるため, その軟化再結晶に伴い機珹的性質は複雑な挙動を示す ことが予想される。

昭和48年 5 月 18 日受付

*大同製鋼㑣研究開発本部中央研究所, 工博

**大同製鋼侏研究開発本部中央研究所
ところがこれまで Cu-Fe 合金に関する研究として は，少量（数\%）の $\mathrm{Cu}$ または $\mathrm{Fe}$ を含む $\mathrm{Cu}-\mathrm{Fe}$ 合

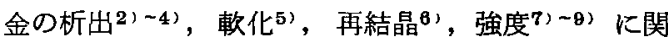
するもの，数 $10 \%$ Fe を含む $\mathrm{Cu}-\mathrm{Fe}$ 合金の強度 ${ }^{10}$ －12)に関するものが知られているが，数10\%の Fe を 含む $\mathrm{Cu}-\mathrm{Fe}$ 合金の軟化および再結晶，ならびにそれ に伴 5伸びおよび強度の変化についてはほとんど知ら れていない。

そこでこれらの挙動を調べたので以下その結果につ いて報告する。

2. 供 試材

Table 1 に供試材の化学組成を示す。ここで $\mathrm{M}$ は プラズマ誘導炣 $\left.\left.{ }^{18}\right) ， 14\right)$ で溶解したもの (250kg インゴ ット）を，Vは真空誘道炬で溶解したもの（15kgイン 
Table 1. Chemical compositions of specimens (wt.\%).

\begin{tabular}{|c|c|c|c|c|c|c|c|c|c|c|c|c|c|}
\hline Alloys & Furnace & C & $\mathrm{Si}$ & $\mathrm{Mn}$ & $P$ & S & $\mathrm{Ni}$ & $\mathrm{Cu}$ & $\mathrm{Fe}$ & $\mathrm{S} \cdot \mathrm{Al}$ & $\mathrm{I} \cdot \mathrm{Al}$ & $S \cdot N$ & $\mathrm{I} \cdot \mathrm{N}$ \\
\hline $\mathrm{Cu}-50 \mathrm{Fe}$ & M $1{ }^{* 1}$ & .003 & $<.01$ & .42 & .004 & .008 & $<.02$ & 49.4 & 49.5 & .005 & 002 & .00 & .001 \\
\hline $\mathrm{Cu}-50 \mathrm{Fe}$ & $\mathrm{M} 2{ }^{* 1}$ & .003 & $<.02$ & .53 & .004 & .009 & .09 & 49.4 & 50.8 & $<.002$ & .004 & & - \\
\hline $\mathrm{Cu}-30 \mathrm{Fe}$ & M $3^{* 1}$ & .002 & $<.02$ & .67 & .005 & .009 & .08 & 69.9 & 29.7 & .011 & .005 & & - \\
\hline $\mathrm{Fe}-7.0 \mathrm{Cu}$ & $\mathrm{V}_{1} * 2$ & .011 & $<.02$ & .51 & .005 & .008 & $<.02$ & 7.0 & Bal. & & 102 & & 06 \\
\hline $\mathrm{Cu}-30 \mathrm{Fe}$ & $\mathrm{V} 2 *_{2}$ & .016 & $<.02$ & .53 & .007 & .003 & $<.02$ & 69.6 & 29.6 & $<.002$ & $<.002$ & .002 & $<.002$ \\
\hline $\mathrm{Cu}-3.4 \mathrm{Fe}$ & $\mathrm{V} 3 * 2$ & .003 & $<.02$ & .54 & .006 & .002 & $<.02$ & Bal. & 3.4 & $<.002$ & $<.002$ & .002 & $<.002$ \\
\hline
\end{tabular}

* 1 Plasma induction furnace

* 2 Vacuum induction furnace

ゴット)を示す。このうち $\mathrm{Fe}-7.0 \% \mathrm{Cu}$ 合金, $\mathrm{Cu}$

$3.4 \% \mathrm{Fe}$ 合金は比較材として溶解した。

$\mathrm{Cu}-50 \% \mathrm{Fe}$ 合金 (M 1， M 2) は 43.8，45.1, 86. 3\%の冷間線引きによってそれぞれ直径 $3.3 ， 2.0$, $2.0 \mathrm{~mm}$ の線にし $\mathrm{Cu}-30 \% \mathrm{Fe}$ 合金（M 3) は45.1, 86. 3，95.0\%の冷間線引きによってそれぞれ直径2.0, 2.0，0.2mm の線にした。いっぼう Fe-7.0\%Cu 合金, $\mathrm{Cu}-30 \% \mathrm{Fe}$ 合金, $\mathrm{Cu}-3.4 \% \mathrm{Fe}$ 合金は $91.4 \%$ の冷間 線引きによって直径 $3.8 \mathrm{~mm}$ の線にした。

\section{3. 实 験 方 法}

\section{1 引張 試睑}

島津製オートグラフ（20 t）を用い，試験片のサイ ズはJ I S 9 号A，ひずみ速度は $8 \times 10^{-4} \mathbf{s e c}^{-1}$ で引 張試験を行ない, 引張強さ，伸び，较りの測定，応力 一ひずみ線図の記録㧊よびn 值の測定を行なった。試 験はすぺて室温 $\left(20^{\circ} \mathrm{C}\right)$ で行なった。

\section{2 変態点測定}

富士電波製の Formaster-F を用い，試験片のサ イズは $4.0^{\$} \times 10^{l}$ ，加熱速度は $900^{\circ} \mathrm{C} / 10 \mathrm{~min} \sim 2 \mathrm{hr}$, 保持温度は $900^{\circ} \mathrm{C}$, 冷却速度は $900^{\circ} \mathrm{C} \rightarrow 150^{\circ} \mathrm{C} / 1 \mathrm{~min} \sim$ $2 \mathrm{hr}$ で処理し，かたさ，変態点の測定および組織の 観察を行なった。

\section{3 組 紸 観 察}

光学顕微鏡掞よび電子顕微鏡のレプリカ像により線 引きのまま之熱処理後との組織を観察した。腐食は， $10 \%$ 過硫酸アンモニウム水溶液（8容）十フンモニ 水（2容）で行なった。

\section{4 䄉維組織䚁察}

理学電機製のガイガー・フレックスを用い，X線管 球は Mo，管電圧は $40 \mathrm{kV}$ ，管電流は $18 \mathrm{~mA}$ の条件
で，写真法により測定した。

試料は $\mathrm{Cu}-30 \% \mathrm{Fe}$ 合金の直径 $0.2 \mathrm{~mm}$ の線で, 線 引きのままおよび焼なまし処理を施したものを，50\% 硝酸水溶液中で直径 $80 \mu$ 程度まで化学研摩して実験に

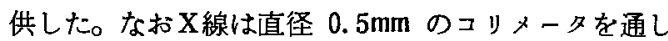
て試料軸に垂直に照射した。

\section{4. 実 験 結 果}

\section{4. $1 \mathrm{Cu}-\mathrm{Fe}$ 合金の软化举動と変態}

Fig. 1 に冷間加工を施した $\mathrm{Cu}-50 \% \mathrm{Fe}$ 合金（M 1）の焼なましによる軟化挙動を示す。 $300^{\circ} \mathrm{C}$ 付近で の烧なましによる硬化は，Cu の析出によるものと考

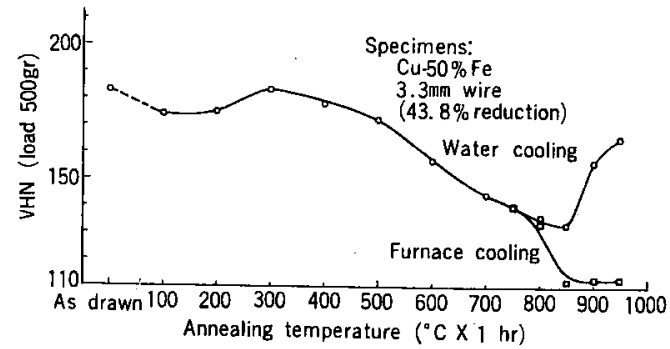

Fig. 1. Softening behavior of $\mathrm{Cu}-50 \% \mathrm{Fe}$ alloy.

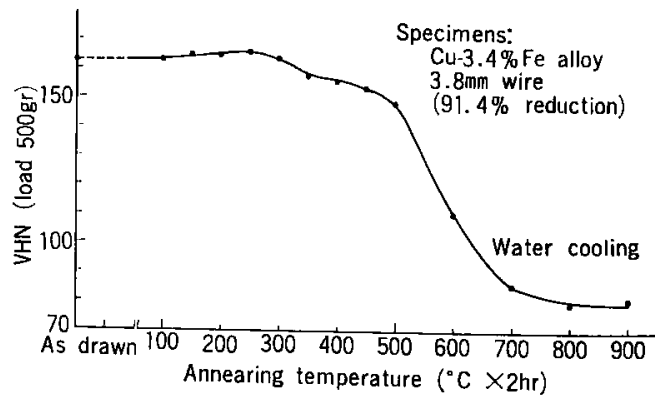

Fig. 2. Softening behavior of $\mathrm{Cu}-3.4 \% \mathrm{Fe}$ alloy. 
えられる2)。さらに加熱温度が高くなるとかたさは低 下してくるが, $750^{\circ} \mathrm{C}$ 以上に加熱したものに保持後水 冷と炉冷の両処理を行なったところ, $800^{\circ} \mathrm{C}$ 付近から

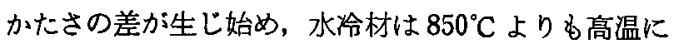
加熱したものではかたさが増加している。いっぽ5炻

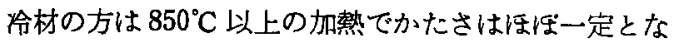
る。

いっぽ5 Cu-3.4\%Fe 合金 (V 3) は Fig. 2 に 示すよ5に水冷してあかたさは増加せず，加熱温度を 高めるに鿒ってかたさは低下し $800^{\circ} \mathrm{C}$ 以上の加熱でほ ぼ一定となっている。

ところで $\mathrm{Cu}-50 \% \mathrm{Fe}$ 合金には常温では体積にして $50 \sim 55 \% の \alpha$ 相があり，変態点以上からの椧却で共 析変態を起こし，いっぽ $5 \mathrm{Cu}-3.4 \% \mathrm{Fe}$ 合金は共析 変態を起こさないことが知られている15)。共析変態 の存在が, 前揭の Fig. 1 における加熱温度 $800^{\circ} \mathrm{C}$ 以 上でのかたさの変化に, 何らかの寄与をしているもの と推測できるので $\mathrm{Cu}-\mathrm{Fe}$ 合金の変態について調へ た。 Table 2 K Cu-50\% Fe 合金 (M 2) と, $\mathrm{Cu}-$ $30 \% \mathrm{Fe}$ 合金（M 3）の加熱および冷却時の変態点を 示す。 $\mathrm{Cu}-50 \% \mathrm{Fe}$ 合金の場合変態開始温度は $829^{\circ} \mathrm{C}$, 変態終了温度は $867^{\circ} \mathrm{C}$ と測定され，従来報告されてい る $\mathrm{Cu}-\mathrm{Fe}$ 合金の共析変態点に活ほ等しい。

Table 2. Transformation point of $\mathrm{Cu}-\mathrm{Fe}$ alloys.

\begin{tabular}{c|c|c|c|c}
\hline \multirow{2}{*}{ Alloys } & \multicolumn{2}{|c|}{ Transformation point $\left({ }^{\circ} \mathrm{C}\right)$} \\
\cline { 2 - 5 } & \multicolumn{2}{|c|}{ Heating } & \multicolumn{2}{c}{ Cooling } \\
\cline { 2 - 5 } & Start & Finish & Start & Finish \\
\hline $\mathrm{Cu}-50 \% \mathrm{Fe}$ & 829 & 867 & 785 & 704 \\
$\mathrm{Cu}-30 \% \mathrm{Fe}$ & 815 & 855 & 797 & 750 \\
\hline
\end{tabular}

Heating rate $: 200^{\circ} \mathrm{C} / \mathrm{hr}$

Holding condition : $900^{\circ} \mathrm{C} \times 10 \mathrm{~min}$

Cooling rate $: 200^{\circ} \mathrm{C} / \mathrm{hr}$

またこの変態点は，Fig. 1 における水冷によって 硬化しはじめる温度とも卧湾一致している。なお， $\mathrm{Cu}-3.4 \% \mathrm{Fe}$ 合金試料ではこのよ5な変態点は認めら れなかった。

前揭の水冷材と炉冷材に認められるがたさ差は， 共析変態の存在だけでは充分には説明できないので， つぎに冷却速度の影響を調ぺた。

Table 3 に示すよ 5 に, 冷却速度を $6.3 \sim 750^{\circ} \mathrm{C} /$ min とかえて冷却速度とかたさおよび変態点との関 保を調へた。冷却速度が大きい活どかたさは堌加し， $750^{\circ} \mathrm{C} / \mathrm{min}$ の場合には $6.3^{\circ} \mathrm{C} / \mathrm{min}$ の場合に比べてビ ッカースかたさで34の上昇が認められた。 $750^{\circ} \mathrm{C} / \mathrm{min}$ の冷却材では, 通常の共析変態とは別に $490^{\circ} \mathrm{C}$ に新し い変態点がめいりょ5に認められた。Fig. 1 の水冷 材の場合は，これより冷却速度が大きいのでさらにか たくなるものと思われる。

Table 3. Effect of cooling rate on transformation point.

\begin{tabular}{|c|c|c|c|c|c|}
\hline \multicolumn{2}{|c|}{$\begin{array}{l}\text { Cooling rate } \\
\left(900^{\circ} \mathrm{C} / 150^{\circ} \mathrm{C}\right)\end{array}$} & \multicolumn{3}{|c|}{$\begin{array}{c}\text { Transformation } \\
\text { point }\left({ }^{\circ} \mathrm{C}\right)\end{array}$} & \multirow{3}{*}{ VHN } \\
\hline \multirow{2}{*}{ Time } & \multirow{2}{*}{${ }^{\circ} \mathrm{C} / \mathrm{min}$} & \multicolumn{2}{|c|}{ I } & \multirow{2}{*}{$\underset{\text { Start }}{\mathbb{I l}}$} & \\
\hline & & Start & Finish & & \\
\hline $2 \mathrm{hr}$ & 6.3 & 770 & 670 & & 114 \\
\hline $1 \mathrm{hr}$ & 12.5 & 742 & 600 & & 121 \\
\hline $12 \mathrm{~min}$ & 62.5 & 718 & 597 & & 132 \\
\hline $1 \mathrm{~min}$ & 750 & 690 & 580 & 490 & 148 \\
\hline
\end{tabular}

Specimen : $\mathrm{Cu}-30 \% \mathrm{Fe}$ Hardness 102 (VHN)

この低温での変態生成物を確認するために組織観察 を行なった。結果を Photo.1に示したか，低温変態 生成物に相当する組織は認められない。また $\alpha$ 相中 には析出した $\varepsilon$ 相， $\varepsilon$ 相中には Cu 合金が再結晶した 場合によく見られる双晶らしいるのか想められる。

$850^{\circ} \mathrm{C}$ 以上の加熱後に水冷処理してかたさが増加す るのは, 変態点以上に加熱した際 $\alpha+\varepsilon \rightarrow r$ で生成し た $r$ が急冷中にマルテンサイト様に変態するものと

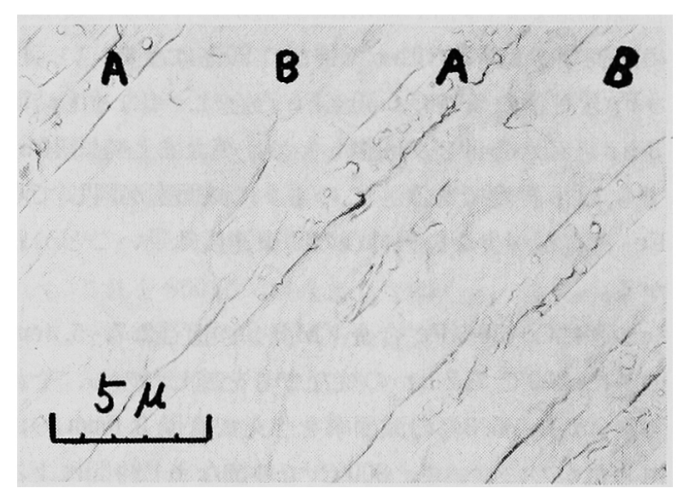

Photo. 1. Influence of cooling rate on microstructure.

Specimens : $\mathrm{Cu}-30 \% \mathrm{Fe}$ alloy, 4. $0 \mathrm{mlm}$ wire, cooling rate $: 750^{\circ} \mathrm{C} / \mathrm{min}$ A are $\alpha$ phases and B are $\varepsilon$ phases. The precipitates which,are observed in $\alpha$ phases are $\varepsilon$ phases. 
推察されるが，組織との対応づけはできなかった。 冷間加工を施した $\mathrm{Cu}-\mathrm{Fe}$ 合金の焼なましにおいて およそ $830^{\circ} \mathrm{C}$ 以上での高温焼なましの場合には変態を 生ずるので，この温度を境として軟化挙動を分けて考 える必要がある。以下の实験では $800^{\circ} \mathrm{C}$ を最高温度 として，この温度以下での低温烧なましによる軟化， 再結晶に伴万機珹的性皿, 䋐維組䋨の变化について調 ベた。

\section{4. $2 \mathrm{Cu}-\mathrm{Fe}$ 合金の機械的性賈と再結晶}

直径 $5.4 \mathrm{~mm}$ の $\mathrm{Cu}-30 \% \mathrm{Fe}$ 合金 (M 3) および $\mathrm{Cu}$ $50 \% \mathrm{Fe}$ 合金（M 2 ）の線に, $800^{\circ} \mathrm{C}$ で $2 \mathrm{hr}$ の㑕なま しを行なったのち，加工減面率86.3\%の線引きを施し て $2.0 \mathrm{~mm}$ の線を得た。これを $800^{\circ} \mathrm{C} て ゙$ 焼なましした 場合の時閒による伸びの変化 をFig. 3 に示す。両者 とも娍面率が $86.3 \%$ と同じであるにもかかわらず， 伸びの回復速度はかなり異なっている。 $\mathrm{Cu}-300 \% \mathrm{Fe}$

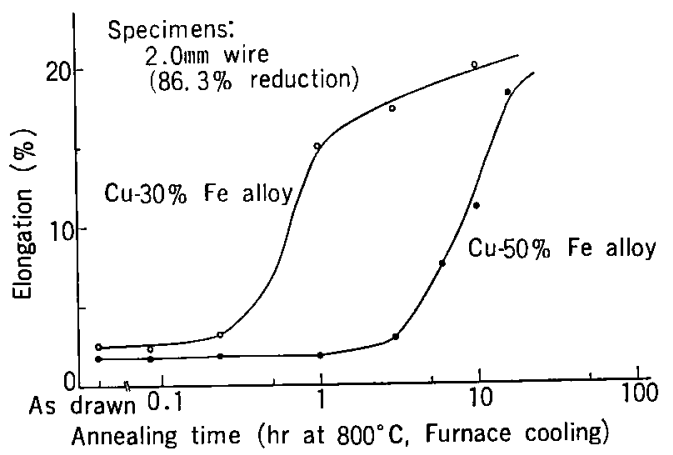

Fig. 3. Change of elongation with annealing time (I).

合金は烧なまし時間 $20 \mathrm{~min}$ 近辺から伸びが回復し始 め，焼なむし時間 $10 \mathrm{hr}$ で伸びは $20 \%$ になる。いっぼ $5 \mathrm{Fe}$ 含有量の多い $\mathrm{Cu}-50 \% \mathrm{Fe}$ 合金は，烧なまし時閒 $3 \mathrm{hr}$ 近辺から伸びが回復し始め, 筧なまし時間 $10 \mathrm{hr}$ でむ $12 \%$ 程度である。このように減面率が同じでも $\mathrm{Fe}$ 含有量が少ない程伸びの回復速度は早いことがわ かる。

つぎにCu-30\% Fe 合金（M 3）の直径2.7, $5.4 \mathrm{~mm}$ の線に $800^{\circ} \mathrm{C}$ で $2 \mathrm{hr}$ の烧なましを施したのち，それ それ 45.1，86.3\%の減面率を与えて直径 $2.0 \mathrm{~mm}$ の線 にしたものについて，800 C での焼なまし時間による 伸びの変化を Fig. 4 に示す。

これら二つは線引き前の直径 $2.7,5.4 \mathrm{~mm}$ の場合 にはほ恬同様な引張強さ（43.8お よび $40.0 \mathrm{~kg} / \mathrm{mm}^{2}$ )， 伸び（27.8および30.0\%）を示していたにもかかわら ず，減面率の大小によって伸びの回復速度にかなりの 差が生じている。45.1\%の減面率を与光た場合には， わずか $30 \mathrm{sec}$ 程度の焼なましで伸びが $20 \%$ を越党る

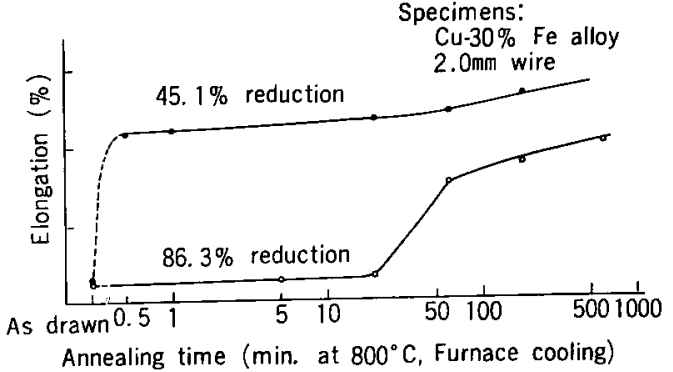

Fig. 4. Change of elongation with annealing time (II).

のに対し，86.3\%の減面率を与克た場 合には $10 \mathrm{hr}$ を要する。

減面率の大きいものは，小さいものに比へて伸びの 団復速度がかなり逯くなると言えよう。この見象は， マトリックスが 1 相から成っている材料では一般的に は認められないことである。これは微細な混合組織の 存在と関連しているのであろ5。

つぎ $\mathrm{Cu}-30 \% \mathrm{Fe}$ 合金（M 3）の減面率がそれぞ

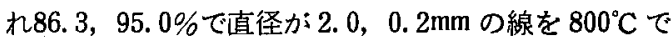
筧なました場合の引張強さと伸びの時間による変化を Fig. 5 に示す。

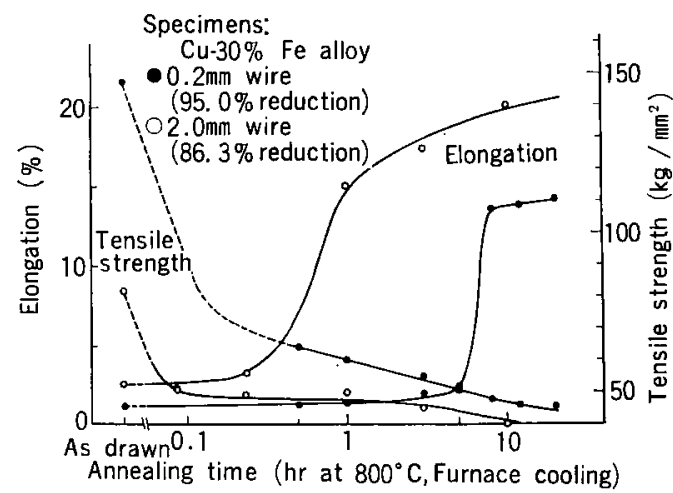

Fig. 5. Change of elongation with annealing time (III).

まず伸びをみると直径 $2.0 \mathrm{~mm}$ の線は $20 \mathrm{~min}$ の焼な ましで伸びが回復し始め，1 hrで15\%，10hr で20\% に達する。いっぽ5直径 $0.2 \mathrm{~mm}$ の線は $3 \mathrm{hr}$ の焼な ましで伸びが回復し始め，8 hr でほほ跑和して13〜 15\%となる。減面率か８％程度異なっているので線径 の影響は正確には分離して評価できないが，線径が小 さくなる程伸びの回復速度が幄くなるよ5である。

それに対し引張強さの方はかなり異なった挙動を示 している。たとえば直径2.0mmの線の場合，伸びが洼 とんど変化しない $5 \mathrm{~min}$ の焼なましで，引張強さは $81.7 \mathrm{~kg} / \mathrm{mm}^{2}$ から $51.1 \mathrm{~kg} / \mathrm{mm}^{2}$ まで約 $30 \mathrm{~kg} / \mathrm{mm}^{2}$ む 低下しているのに, 伸びが3.2\%から 15.0\%と急激に 変化する $20 \mathrm{~min}$ から， $1 \mathrm{hr}$ の焼なましで弓張強さは 
$49.1 \mathrm{~kg} / \mathrm{mm}^{2}$ から $49.7 \mathrm{~kg} / \mathrm{mm}^{2}$ とほとんど変化して ない。

すなわち伸びの回復は引張強さの低下と対応してな くてそれより僬れて起こることがわかる。このよ5な 遲れは直径 $0.2 \mathrm{~mm}$ の線の場合でる認められる。

そこでこの伸びの回復を支配しているものが何かを

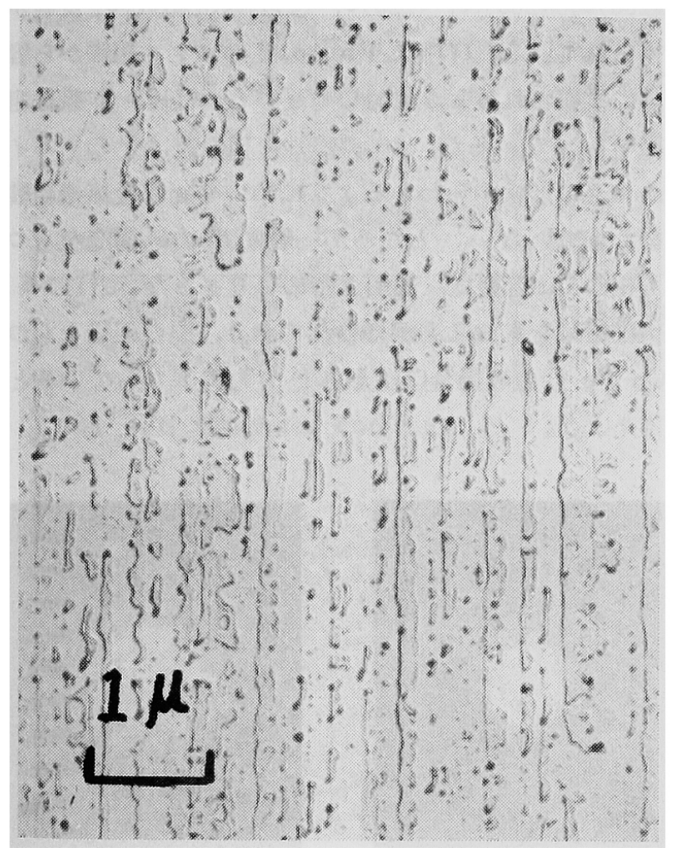

(a) As drawn

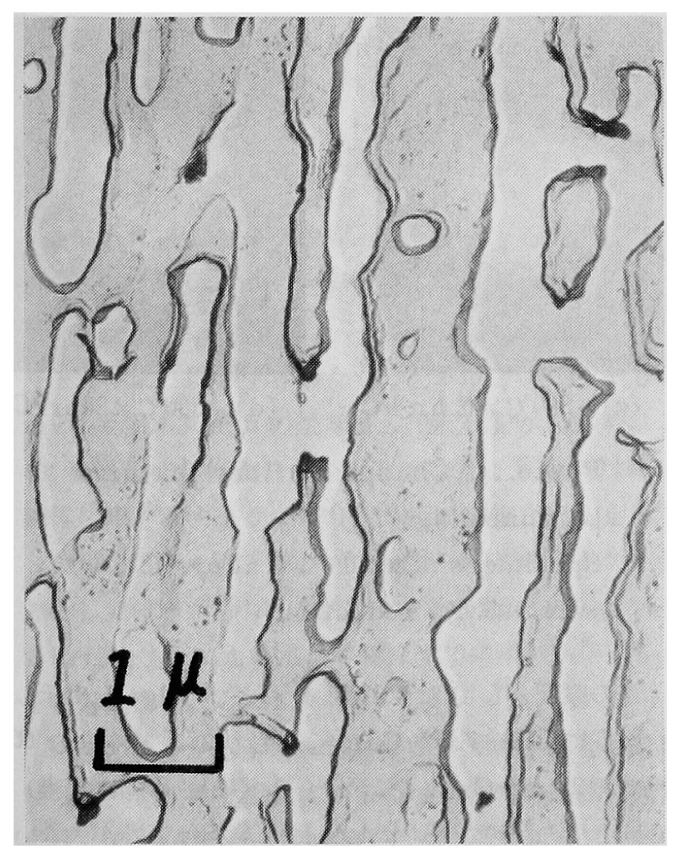

(b) $800^{\circ} \mathrm{C} \times 300 \mathrm{~min} \mathrm{FC}$

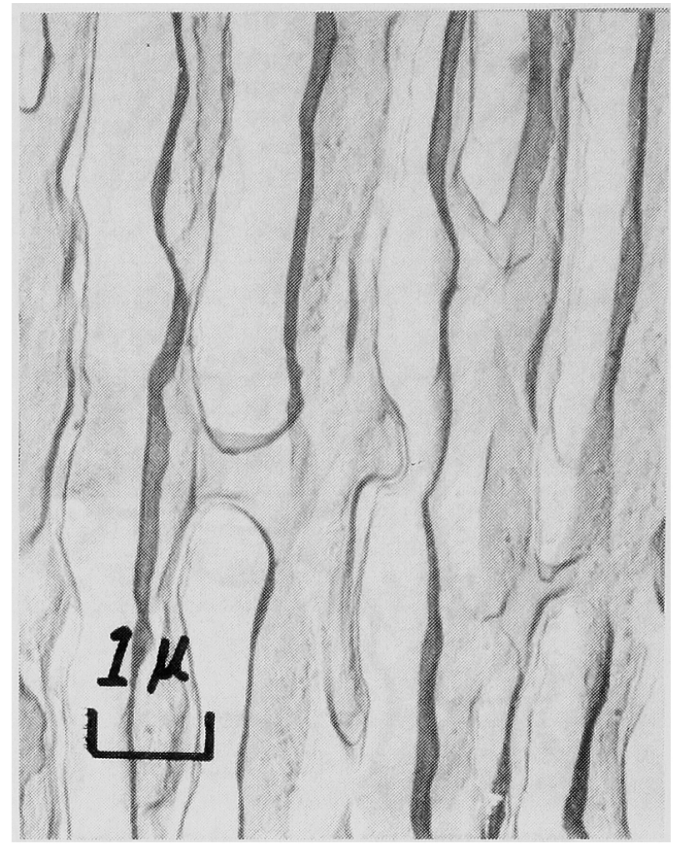

(c) $800^{\circ} \mathrm{C} \times 5 \mathrm{hrFC}$

Photo. 2. Change of microstructure by annealing ( I ).

Specimens : $\mathrm{Cu}-30 \% \mathrm{Fe}$ alloy, $0.2 \mathrm{~mm}$ wire $(95.0 \%$ reduction)

調ベるためにレプリカ像によってミクロ組織の観察を 行なった。Photo. 2, 3 K, Fig. 5 で示した直径 $0.2 \mathrm{~mm}$ の線の線引きしたをむの組織および $800^{\circ} \mathrm{C}$ で $30 \mathrm{~min}, 5 \mathrm{hr}, 12 \mathrm{hr}, 20 \mathrm{hr}$ 焼なました場合の組織 を示す。Photo. 2 (a)により $\mathrm{Cu}-30 \% \mathrm{Fe}$ 合金の $\alpha$ 相 は線引きによてき的めて細かく分断されたファイハ 状の組織になっていることがわかる。このファイバは 線引き方向に延びているが，それに垂直な方向の愊

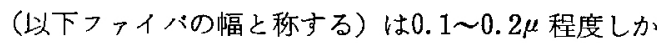
ない。これを $800^{\circ} \mathrm{C} て ゙$ 焼なましてゆくと，伸びの余り 変化しない焼なまし時間 $5 \mathrm{hr}$ 近辺まではこのファイ バの幅子余り変化してない。しかしながら伸びの変化 する $5 \mathrm{hr}$ から $12 \mathrm{hr}$ にかけて, ファイバの幅も急激 に変化し $12 \mathrm{hr}$ ではその大きさは漂㴗飽和し，20hr 焼なまし時のファイバの幅とほとんど変らなくなって いる。この間伸びの方もほぼ飽和している。なおこの 間 $\varepsilon$ 相の変化は余り顕著ではない。

以上のことから $\varepsilon$ 相と $\alpha$ 相との混合組織からなる $\mathrm{Cu}-\mathrm{Fe}$ 合金の伸びの回復に刘し, ファイバ状の $\alpha$ 相 の成長が大きく影響していることが推察される。

しかしながら，焼な委し時の $\varepsilon$ 相の再結晶の挙䃼が 


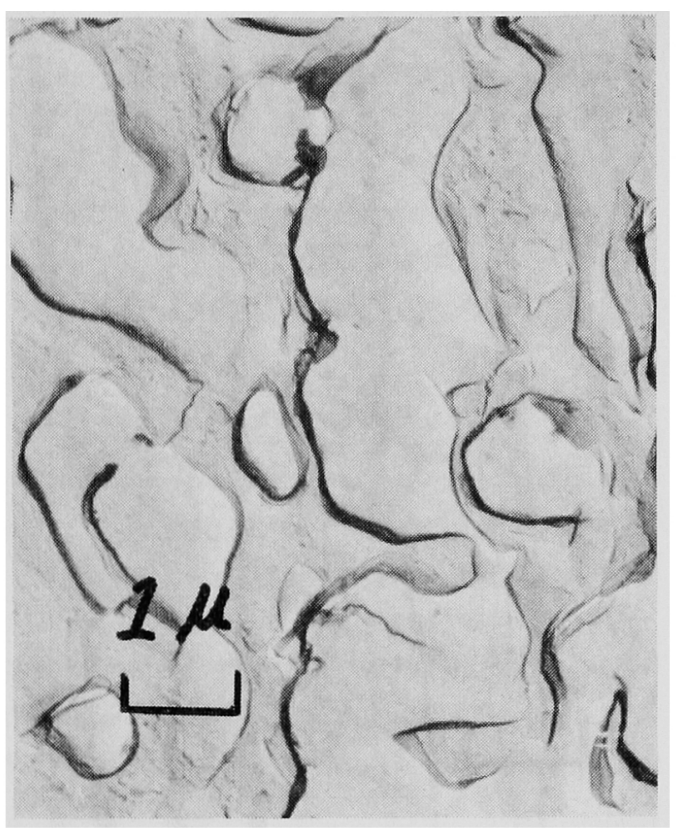

(d) $800^{\circ} \mathrm{C} \times 12 \mathrm{hr} \mathrm{FC}$

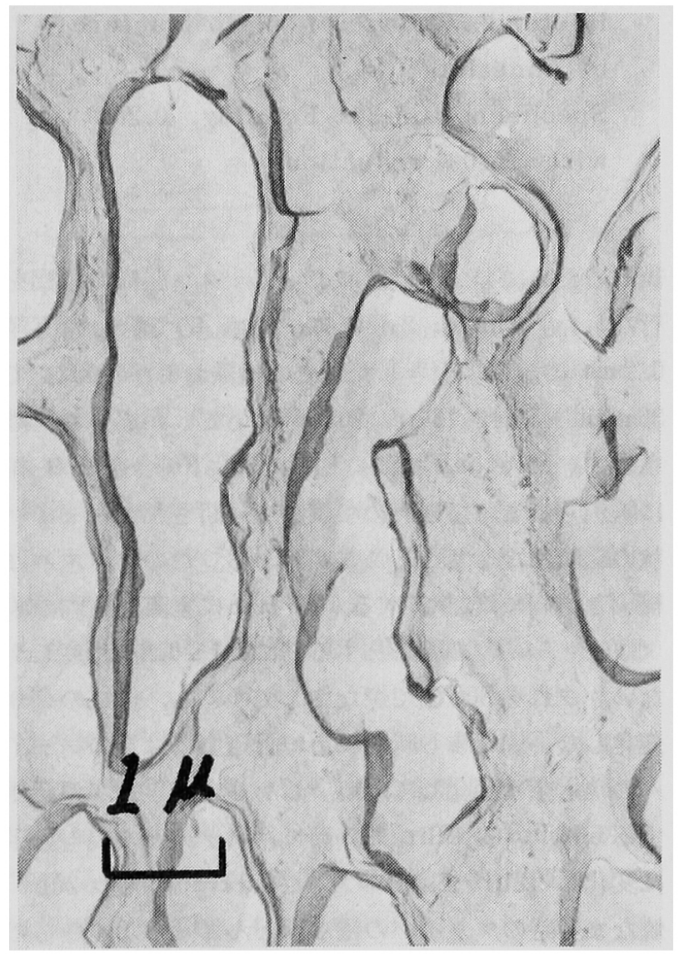

(e) $800^{\circ} \mathrm{C} \times 20 \mathrm{hr} \mathrm{FC}$

Photo. 3. Change of microstructure by annealing (II).

Specimens : $\mathrm{Cu}-30 \% \mathrm{Fe}$ alloy, $0.2 \mathrm{~mm}$ wire (95.0\% reduction)
レプリカ像の観察によっては,はっきりしなかったの で, 同じ直径 $0.2 \mathrm{~mm}$ の 線に対してX線回折によって 絒維組織の観察を行なった。

Photo. 4 に線引きしたままの緎維組織および $800^{\circ} \mathrm{C}$ で 30min，2 $\mathrm{hr}, 20 \mathrm{hr}$ 烧なました場合の㵶維組織を 示す。Photo. (a) は線引き時の繊維組織であるが，中 心から測定して半径の小さい順に (111) $\varepsilon ，(110) \alpha$, (200) $\varepsilon,(200) \alpha,(220) \varepsilon,(211) \alpha$, (311) $\varepsilon$ 反射 得られている。 $\alpha$ 相は Photo. 2 のミク口組繶から容 易に推察されるようにめいりょうなく110> $\alpha$ 繊維組 織をもっているが，いっぼ5 $\varepsilon$ 相の力はそのデパイ リングの形状からわかるよ5にめいりょ5な繊維組織 をもっていない。ところが一般に $\mathrm{f} \cdot \mathrm{c} \cdot \mathrm{c}$ 構造をむつ 1 相の $\mathrm{Cu}$ 合金は，線引き時めいりょ 5 な $<111>\varepsilon$ 緫維組織をもつことが知られており，混合組織をもつ $\mathrm{Cu}-\mathrm{Fe}$ 合金の場合にはそれとかなり異なっていると 局克よ5。

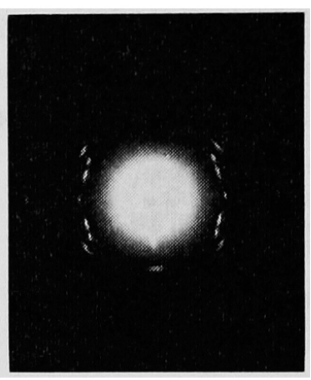

(a) As drawn

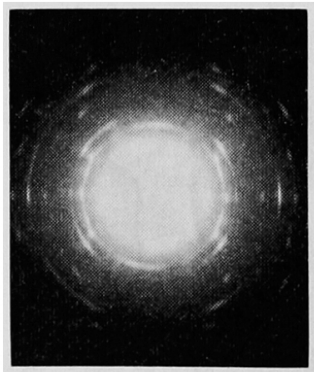

(c) $800^{\circ} \mathrm{C} \times 2 \mathrm{hr} \mathrm{FC}$

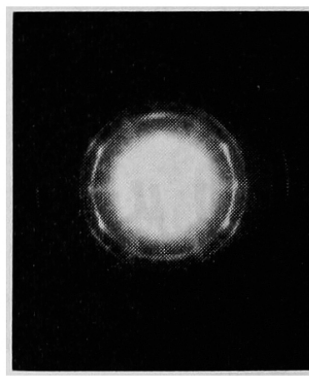

(b) $800^{\circ} \mathrm{C} \times 30 \mathrm{minFC}$

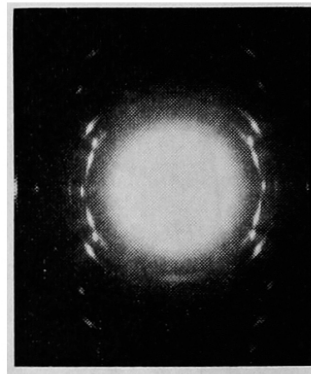

(d) $800^{\circ} \mathrm{C} \times 20 \mathrm{hrFC}$
Photo. 4. Change of fiber textures by annealing.

Specimens : $\mathrm{Cu}-30 \% \mathrm{Fe}$ alloy, $0.2 \mathrm{~mm}$ wire $(95.0 \%$ reduction)

この原因としては Table 4 および Fig. 6 に示し たよ $5 に ， \mathrm{Fe}-7.0 \% \mathrm{Cu}$ 合金（粒状の $\varepsilon$ 相を含む $\alpha$ 相に相当) は $\mathrm{Cu}-3.4 \% \mathrm{Fe}$ 合金（ほ潘 $\varepsilon$ 相に相当） の約 2 倍の強度をもち，いっぼ $5 \varepsilon$ 相は延性が大きい ため変形が不均一に起こって Fe-rich 相が大きく変 
Table 4. Mechanical properties of $\mathrm{Cu}-\mathrm{Fe}$ alloys.

\begin{tabular}{|c|c|c|c|c|c|c|}
\hline Diameter of wire & Alloys & Heat' treatment & \begin{tabular}{|c|} 
Tensile \\
strength \\
$\left(\mathrm{kg} / \mathrm{mm}^{2}\right)$
\end{tabular} & $\underset{(\%)}{\text { Elongation }}$ & $\begin{array}{c}\text { Reduction } \\
\text { of area } \\
(\%)\end{array}$ & $\underset{\text { value }}{n}$ \\
\hline \multirow{6}{*}{$\begin{array}{c}3.8 \mathrm{~mm} \\
(91.4 \% \text { reduction })\end{array}$} & \multirow{2}{*}{$\mathrm{Cu}-30 \% \mathrm{Fe}$} & As drawn & 90.5 & 3.9 & 50.5 & - \\
\hline & & $800^{\circ} \mathrm{C} \times 5 \mathrm{hr}^{* 1} \mathrm{FC}$ & 42.3 & 28.3 & 79.5 & 0.30 \\
\hline & \multirow{2}{*}{$\mathrm{Fe}-7.00^{\circ} \mathrm{Cu}$} & As drawn & 105.1 & 4.6 & 65.4 & - \\
\hline & & $800^{\circ} \mathrm{C} \times 5 \mathrm{hr} F \mathrm{FC}$ & 54.9 & 24.9 & 80.2 & 0.28 \\
\hline & \multirow{2}{*}{$\mathrm{Cu}-3.4 \% \mathrm{Fe}$} & As drawn & 55.5 & 4.7 & 75.2 & - \\
\hline & & $800^{\circ} \mathrm{C} \times 5 \mathrm{hr} \mathrm{FC}$ & 31.2 & 35.4 & 89.2 & 0.38 \\
\hline \multirow{2}{*}{$\begin{array}{c}2.0 \mathrm{~mm} \\
(86.3 \% \text { reduction })\end{array}$} & \multirow{2}{*}{$\mathrm{Cu}-30 \% \mathrm{Fe}$} & As drawn & 81.7 & 3.5 & 60.4 & - \\
\hline & & $800^{\circ} \mathrm{C} \times 6 \mathrm{hr} \mathrm{FC}$ & 39.8 & 17.8 & 74.1 & - \\
\hline \multirow{2}{*}{$\begin{array}{c}0.2 \mathrm{~mm} \\
(95.0 \% \text { reduction })\end{array}$} & \multirow{2}{*}{$\mathrm{Cu}-30 \% \mathrm{Fe}$} & As drawn & 147.8 & 1.2 & - & - \\
\hline & & $800^{\circ} \mathrm{C} \times 8 \mathrm{hr} \mathrm{FC}$ & 48.1 & 13.5 & - & 0.11 \\
\hline
\end{tabular}

*1 FC : Furnace cooling

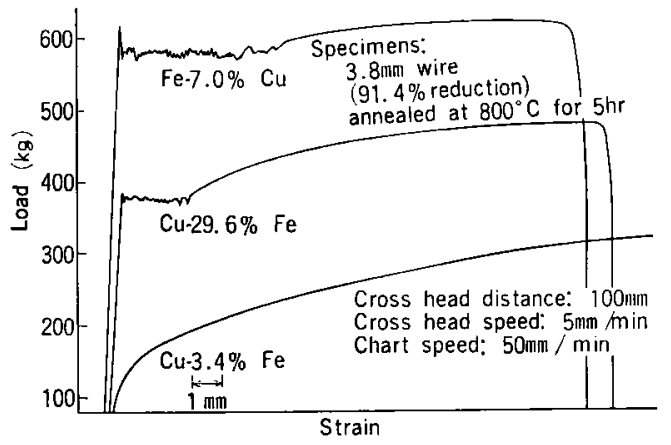

Fig. 6. Stress--strain curves of $\mathrm{Cu}-\mathrm{Fe}$ alloys.

形したことが推察される。

いずれにせよこれは強度，延性の異なる相から成る 混合組織の変形と言う立場で考えると面白い現象であ る。

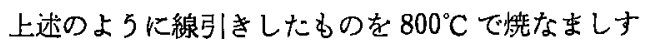

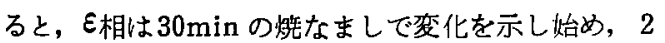
hr の焼なましによってかなりめいりょうなく111>と 織維組織を示すよ $5 に な り ， 20 \mathrm{hr}$ の焼なむしを行な った場合と活とんど異なっていない。このことから全

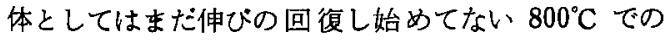
$2 \mathrm{hr}$ 焼なましによって，と相はすでに再結晶してい ると言えよう。

以上のことから $\mathrm{Fe}$ 含有量の多い $\mathrm{Cu}-\mathrm{Fe}$ 合金の伸 びの回復速度を支配しているのは ではなく， $\alpha$ 相の成長速度であり，しかもその $\alpha$ 相 の成長の速度は線引き時のファイバの幅が小さい程遅
いことが推察される，

いっぽう析出相ではなく, マトリックス，しかも混 合組織のマトリックスが微細な場合の再結晶扰よびそ れに伴 5 強度，延性については今後椧討すべきことが 多い。

\section{5. よ め}

冷間加工した後炒なまし処理を施した $\mathrm{Cu}-\mathrm{Fe}$ 合金 の機械的性質を調べ以下の結果を得た。

（1）共析変態以上の盜度領域で保持した後急冷した ものは，徐冷したものに比べてかたさが高く，その差 は冷却速度が大きい程また加熱速度が高い程大きい。

（2）冷間加工状態でもまた焼なまし状態でも， Fe 含有量が多い程，引張強さは大きく，伸びは小さい。

(3) $\mathrm{Fe}$ 含有量が多い程，また減面率が大きい程伸 びの回復速度は遜い。

(4) $85 \%$ 以上の減面率で線引きして直径 $2 \mathrm{~mm}$ 以下 の線にすると， $\alpha$ 相が平均で幅 $0.2 \mu$ 以下の微細なつ フイバ状組織となり， Cu-30\% Fe 合金を $86.3 \%$ 娍

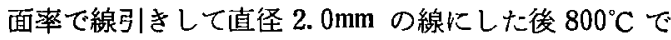
焼なましすると， $1 \mathrm{hr}$ 烧なましして 150。の伸びに達 した。

(5) $95 \%$ 減面淬で線引きして直径 $0.2 \mathrm{~mm}$ の線に した場合には， $\alpha$ 相はめいりょうなく110－ $\alpha$ 䋐 維組織をもっているが，いっぽ5 $\varepsilon$ 相の方は弱い $<111>\varepsilon$ 纎維組織をむつたけである。これを $800^{\circ} \mathrm{C}$ で燃なましすると，きわめてめいりょうな $<111>\varepsilon$ 繊維組織が得られることから， $\varepsilon$ 相は伸びの回愎に先 行して再結晶することを認めた。 
（6）伸びの回復は引張強さの低下にかなり遮れて起 こる。作びの回復はファイバ状の $\alpha$ 相がある一定の 大きさに成辰して初めて起こること，およびファイバ 状の $\alpha$ 相の成長と伸びの回復とに相関のあることを 認めた。

（文 献）

1）竹内：日本金癗学会誌，31（1967） 10, 1133.

2) 添野：日本金属学会誌，31 (1967) 11，1309.

3）美馬：日本金属学会誌，31（1967）6，761.

4) E. Hornbogen : Trans. AIME., 218 (1960) $12,1064$.

5）美馬：日本金属学会誌，33 (1969) 5，521.

6) E. Hornbogen : Arch. Eisenhüttenwes, 41 (1970) 5, 439.
7) E. Hornbogen : Trans. ASM., 57 (1964), 120.

8) Le May : JISI., 208 (1970) 5, 458.

9）佐治：大阪治金会会誌, (1970) 11, 63.

10) S. Floreen : Trans. AIME., 245 (1969) 12, 2529.

11）美馬：日本金属学会誌, 35 (1971) 3, 223.

12）室町：日仿伸銅技術研究会誌，7(1968) 1, 118.

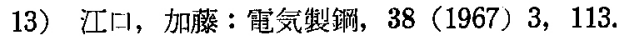

14）野田，浅田，江口，足立，林：電気整鐥，41 (1970) 4, 267.

15) M. Hansen : Constitution of Binary Alloys, 580 582, McGraw-Hill Book Company, Inc., New York, 1958.

\section{連鋳の

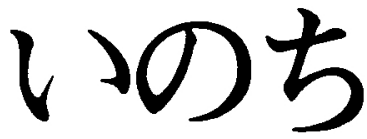

世界的にその優秀性を評価されている TRCの連続鋳造用耐火物

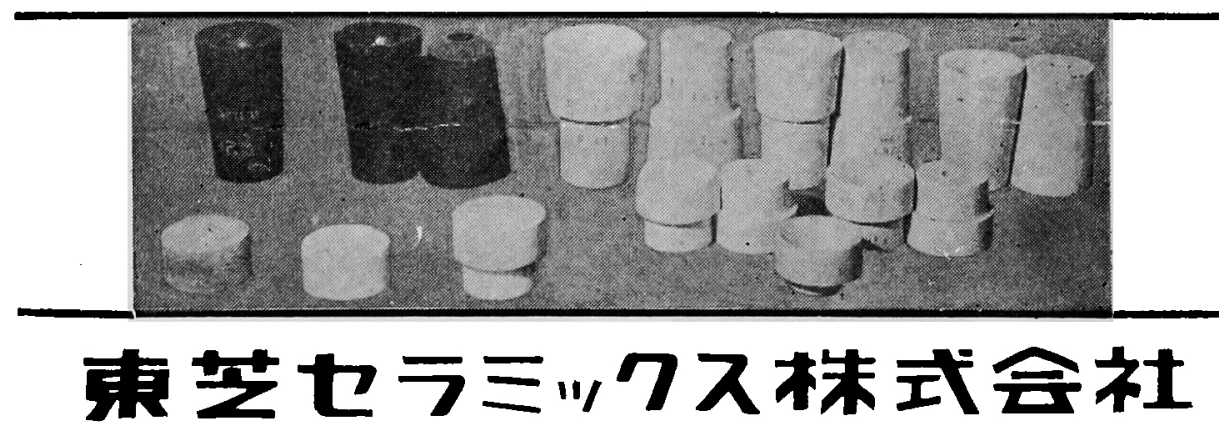

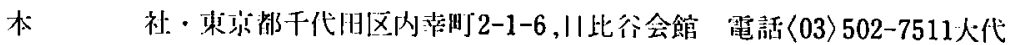

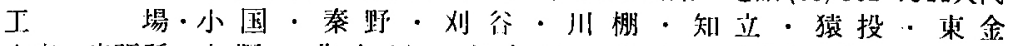

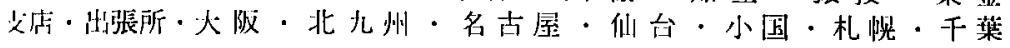

